\title{
Cancer in Women and Its Relation to Work Systematic Review
}

\author{
Maria Teófila Vicente-Herrero ${ }^{1^{*}}$ (D), Maria Victoria Ramírez-Iñiguez de la Torre ${ }^{2}$ (), \\ Luisa Capdevila García ${ }^{3}$ (i)
}

\author{
${ }^{1}$ Asociacion Española de Especialistas en Medicina del Trabajo, Occupational Health and Safety Services of SPP Correos, \\ Valencia, Spain \\ ${ }^{2}$ Asociacion Española de Especialistas en Medicina del Trabajo, Occupational Health and Safety Services of SPP Correos and \\ Occupational Health and Safety Services of SPA ITEM-Prevencion, Albacete, Spain \\ ${ }^{3}$ Asociacion Española de Especialistas en Medicina del Trabajo, Occupational Health and Safety Services of SPM MAPFRE, \\ Valencia, Spain \\ Email: *vicenteherreromt@gmail.com
}

How to cite this paper: Vicente-Herrero, M.T., Ramírez-Iñiguez de la Torre, M.V. and García, L.C. (2021) Cancer in Women and Its Relation to Work Systematic Review. Occupational Diseases and Environmental Medicine, 9, 74-91.

https://doi.org/10.4236/odem.2021.92007

Received: April 23, 2021

Accepted: May 23, 2021

Published: May 26, 2021

Copyright $\odot 2021$ by author(s) and Scientific Research Publishing Inc. This work is licensed under the Creative Commons Attribution International License (CC BY 4.0).

http://creativecommons.org/licenses/by/4.0/

(c) (i) Open Access

\begin{abstract}
Nowadays, cancer is one of the main worldwide causes of death and an increasing issue in public health. In the European Union, it is the first workrelated cause of death. Studies about occupational risk exposure are a useful field of investigation to determine cancerous elements; special attention is paid to the relationship between cancer and work in women, who must constantly adapt to the working market and the new working fields, with their diverse degrees of exposure to risks. This revision has reviewed the bibliography gathered in Medline related to breast cancer, cervix cancer, uterus cancer, and ovarian cancer, along with their relationship with different workrelated risks and types of working roles. The results have shown enough scientific evidence to suspect that work related exposition could be a plausible cause of these gynaecological cancers. Therefore, we want to stress the need of enhancing the coordinated investigation between all the medical specialties involved, and to encourage the spread of the necessary knowledge to manage and prevent them.
\end{abstract}

\section{Keywords}

Gynaecological Cancer, Breast Cancer, Work-Related Risk Factors, Workplace, Occupational Health

\section{Introduction}

Nowadays, cancer is one of the main worldwide causes of death and an increas- 
ing issue in public health. The current epidemiological data and the evolutional tendency point towards an increment in its frequency, prevalence, and mortality rates happening in the next 40 years, which would comport a global pandemic with sanitary, economic, and social consequences.

The World Health Organisation (WHO) suggests the design of global strategies for the detection and treatment of patients, funding that enhances investigation and collaborative efforts for facing this disease in a more efficient and sustainable way [1].

Both databases of the WHO and the American Cancer Society offer information regarding the frequency, mortality, and survival of the 15 principal types of cancer in the world. The average risk of developing cancer for individuals aged 0 to 74 is $20.2 \%$ ( $22.4 \%$ for men and $18.2 \%)$. Breast cancer is the most frequent type of cancer in women (2.09 million cases worldwide), making it the main cancer-related mortality cause in women; however, it has the highest survival rate in a 5 -year time band $(80 \%-85 \%)$, in contrast with the rate for uterine cancer $(50 \%-70 \%)$ and ovarian cancer $(30 \%-50 \%)$ [2] [3].

\section{Methodology}

The revision has carried out a review of Medline's bibliography, in particular, scientific publications that looked into the relationship between woman specific cancers and work-related risk exposure. This was done using: Scielo, Scholar, Legal test, and PubMed (https://pubmed.ncbi.nlm.nih.gov/), a free access platform with wide international coverage. Even though the limited publishing time of the publications had not been specified, priority was given to work released in the past 5 years, paying special attention to those produced from 2019 onwards. Classified magazines' articles (editorial pieces, manuscripts, letters, reviews, clinic notes) were also included. The search was especially focused on breast cancer, uterine cancer, cervix cancer, and ovarian cancer, using the following terminology: "breast cancer and y occupational risk factor", "uterus cancer and occupational risk factor", "cervix cancer and occupational risk factor", "breast cancer and workplace", "cervix cancer and workplace", "uterus cancer and workplace" and "gynecologic cancer and occupational medicine" (Figure 1) (Table 1).

\section{Cancer in Women: Work-Related Risk Factors}

In the European Union (EU) cancer it is the first work-related cause of death, comporting 53\% of the annual work-related deaths. In Europe, 102,500 [4] deaths were attributed to work-related cancer in 2011, which explains the increasing concern in all countries of the EU regarding the protection of workers against the cancerous elements they are exposed to at the workplace. The European Commission suggests the modification of the Directive of the European Parliament 2004/37/CE, which is relative to the protection of employees against the risks related to their exposure to cancerous or mutagen agents during their working activities; it also limits the exposition at the workplace to thirteen newly 


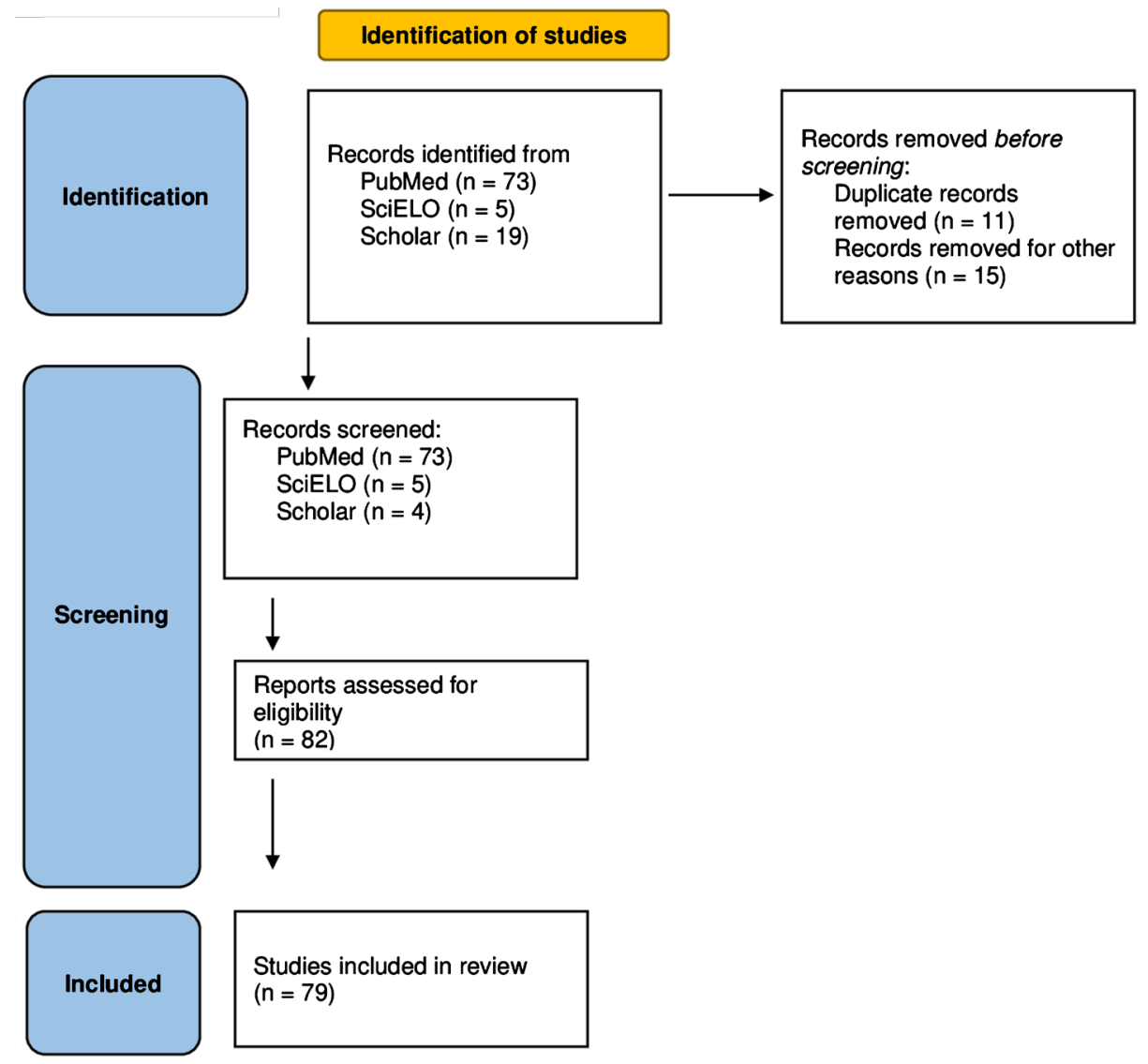

Figure 1. Flow diagram.

Table 1. Outline of the selected studies.

\begin{tabular}{|c|c|c|c|}
\hline Topics & $\mathbf{n}$ & Type of study & Objetive \\
\hline $\begin{array}{l}\text { Cancer in } \\
\text { women: } \\
\text { work-related } \\
\text { risk factors }\end{array}$ & $(\mathrm{n}=44)$ & $\begin{array}{l}\text { Epidemiological, } \\
\text { occupational intervention, } \\
\text { notification and } \\
\text { registration studies }\end{array}$ & $\begin{array}{l}\text { Relate occupational risk } \\
\text { factors and cancer in } \\
\text { women: ovary, uterus, } \\
\text { cervix and breast cancer. }\end{array}$ \\
\hline
\end{tabular}

Conclusions

Cancer in $\quad(n=6) \quad$ Epidemiological studies

Women: Risk

Factors

Outside

Work
Relate occupational and factors and cancer in women: ovary, uterus, cervix and breast cancer. non-occupational risk

It is complex to establish relationships between occupational exposures in specific job sectors and cancer in women. Exposure to chemical and physical agents at work appears to be related to gynecological cancer: pesticides, xenobiotics, hydrocarbons, solvents, radiation or alterations of the circadian rhythm form the most studied group of exposures.

In cancer, genetic factors are relevant, but occupational exposure must be part of the investigation to establish the cause-effect relationship.

In epidemiological studies focused on specific professional groups, a higher incidence or risk of death was observed than the incidence should be related to occupational exposure. However, due to the inconsistency of the results and methodological deficiencies, even today it has not been possible to reach definitive conclusions

Occupational cancer is the lowest reported Occupational

Assess the situation of women's cancer in Spain, studies of prevalence and its legislative regulation Spain. Epidemiological registration.
Disease in Spain and in neighboring countries, and requires a multidisciplinary and collaborative approach to be able to approximate real figures.

To study occupational cancer in women, a gender perspective is required to prevent it.

And facilitate the safe return to work after the illness is over. 
considered as cancerous [5].

Carrying studies on occupational risk exposure allow researchers to keep moving forwards with the identification of cancerous agents; paying special attention to the relationship between cancer and work that affects women, research studies and investigations have been carried out for decades. It is estimated that $1 \%$ of women's cancer is attributed to the patients' working role, but most studies do not show the changes all countries have suffered in terms of women's participation in the working world, nor women's different employment patterns in under-developed countries. The proportion of women with paid jobs, the types of unpaid work, the distribution of women across the different economic sectors, the scale of workplaces, the levels of exposure to risk agents allowed at the workplace, and the implementation of regular controls are some of the factors that have changed over time and that continue to change. New routes are opened for investigators of occupational cancers, widening they span to include preventive activities in under-developed countries, studies about new industries using methods to evaluate the exposure risks, and new molecular epidemiological techniques that facilitate the discovery of new cancerous agents and the identification of better control measures for their prevention [6].

Establishing relations between occupational exposure in specific working sectors and women's cancer is a complex process. For ovarian cancer, an increment of the risk has been found for a variety of employees and sectors; nevertheless, the weight of individual risk factors [7] has frequently been overlooked: hormonal treatments for menopause-related symptoms-the IARC has associated them with an increment of the risk of developing ovarian cancer (IARC, 1999) - age, use of contraceptive methods, gender equality history, breastfeeding or family history [8] [9] [10] [11].

Although progress has been made regarding the identification of personal risk factors and the improvement of treatments for breast cancer, incidence rates keep growing. In 1996, it was suggested that, since women were already a considerable fraction of the working masses, it was worth wondering about the existence of work-related risk factors with an impact on breast cancer. The revision showed a low number of high quality occupational studies focused specifically on women and that enabled the unequivocal identification of work-related factors for this kind of neoplasms. This stressed the need of carrying out investigations that took into account risk factors unrelated to work and the exposition of chemical and physical agents that could be posteriorly related to the appearance of breast cancer, hence complementing cohort studies and investigations of specific demographic groups [12].

A series of diverse work-related risk factors have been identified as possible causes of different types of women's cancer. One of the most studied ones has been the exposition of pesticides in industrialised countries, both due to their cancerous effect and the consequences they have on reproduction. In underdeveloped countries, women are increasingly exposed to pesticides, and their 
toxicity seems to be underestimated. Many of these pesticides' effects will be the same for both men and women, but it is not always the case.

Some organochloride pesticides have been linked with breast cancer in postmenopausal women, but the knowledge about other pesticides is quite limited. Gender sensitive research is necessary to study the gender-environment interactions that could be related to exposure to these substances and the effects they cause on women [13].

Uterine cancer shows a clear genetic predisposition [14]; however, in 1999 the influence of work-related risk exposure on its development was already evaluated, particularly the influence of pesticides. Studies in Costa Rica showed a higher prevalence of breast cancer, uterine cancer and ovarian cancer in urban areas, whilst cervix cancer was more frequent in rural areas. Thus, hypothesis were established, linking the exposure to pesticides with specific types of cancer that act differently on men and women, and that require individualised studies [15].

The exposition to tobacco smoke on men and women has been evaluated, especially in cases of non-smoker women exposed to the smoke in a passive way, and its effect on breast cancer. A study on Chinese women found positive associations and a dose-answer relationship between post-menopausal women who are passively exposed to tobacco smoke and all subtypes of oestrogen and progesterone receptors of breast cancer. This established a significant relationship between them [16]. Tobacco smoke has also been identified as a risk factor for mucinous ovaric tumours [17] [18] but without a clear effect on its mortality rate [19]; it has also been associated with a higher risk of developing cervical adenocarcinoma [20], although it must be taken into account that the consume of tobacco is linked to other factors (immunologic, psychosocial, nutritional) that difficult the evaluation of their role in the genesis of this cancer [21].

The relationship seems clearer between breast cancer and the exposition to both oestrogenic effect hormones and oestrogen-progesterone combinations, with an increment of the risk of developing it [22]. Organochloride solvents and other substances with oestrogenic properties are considered risk factors for uterine cancer since they act as endocrine disruptors that affect the endometrium. But, despite having shown an association with endometriosis, it has not been possible to demonstrate a clear connection with cancer found in this part of the body [23] [24]. Endocrine aspects, obesity and the lack of physical activity seem to increment the risk of uterine cancer. Endocrine factors admit an increment of the risk due to treatments that use certain contraceptive medication and therapies for menopause that contain oestrogens, in isolation or associated with progesterone [25].

Some occupational expositions of chemical nature can contribute to developing cervix cancer. This happens with some dry-clean products: tetrachloroethylene [26] [27] or diverse solvents [28] [29]; they can be a risk in professional sectors such as professional and house cleaning, where a higher than average cervix cancer prevalence has been observed [30] [31]. Another of the evaluated expositions 
of risk is the effect of styrene-butadiene on women who work at rubber factories, linking it with several types of cancer, such as breast cancer and ovarian cancer, but with quite inconclusive results and mortality rates similar to the expected [32].

Others studies have estimated the association of breast cancer with the exposition to polycyclic aromatic hydrocarbons, with results that suggest that a prolonged exposition increments the risk in women with antecedents of breast neoplasm in their family history [33]. The same happens in occupational exposure with certain chemical substances that can cause an endocrinal disruption: ethylene oxide, polycyclic aromatic hydrocarbons (PAHs), diverse biocides and solvents [34]. The risk is high in working sectors such as laboratory technicians and assistants, agriculture, plastic manufacturing, tinned food processing, metallurgy, motor industry, painting, foresters and wood workers, health workers, social workers and furniture makers [35] [36] [37].

Regarding ionizing radiation, whilst the exposition to high amounts is associated with a greater risk of developing breast cancer, its association with prolonged exposition to lower rates hasn't been established. A study by the US Radiologic Technologist offers the opportunity of examining the association between low-medium doses of ionizing radiation and the incidence and mortality rates of breast cancer. Work-related radiation was associated with an increase in the risk of developing it, showing that it was higher for women born before 1930; they started working before 1950, when the annual average dose (37 mGy) was considerably higher than in later years $(1.3 \mathrm{mGy})$. However, due to uncertainties and errors in the dose estimations prior to 1960, these findings must be cautiously considered [38]. Further studies suggest that ionizing radiations in the health sector are associated with the risk of developing breast cancer [39] [40].

A significant number of the studies that evaluate cervix cancer influent factors stress the limitations of their obtained results. This is due to the confusing effect that the human papillomavirus (HPV) has on it, which, being key for cancer's development, is not normally taken into consideration for the epidemiological studies that explore its association with the work-related factors [41]. The presence of the sexually transmitted HPV is considered a requirement for the disease to develop, as well as its highest risk factor [42]. In terms of work-related exposure, a higher risk of cervix cancer in female workers has been linked to a high prevalence of the infection [43].

In the last few years, the exposure risk to cosmic radiation and circadian rhythm alterations has been highlighted in some working contexts, such as flight assistants, observing a higher risk towards certain cancers. A US-centred study evaluated the incidence of thyroid cancer, ovary cancer, and uterine cancer in 6000 female flight assistants, comparing them with the country's general population. The results didn't show big variations regarding the incidence of any of the 3 types, nor any evidence of higher risk. However, the low number of cancer cases that could be observed, the limited data about risk factors, and the misclas- 
sification of exposition types didn't enable the researchers to produce clear conclusions, leaving an open field for future investigations [44]. Nevertheless, what seems to have been possible with this flight assistant collective is to establish a higher risk of breast cancer; this was showed in a revision carried out between 1995 and 2013, with incidence data, unlike mortality rates, being significantly higher. The explanation seems to lay in the alterations of the circadian rhythm produced by night shifts and the changes of time zones, which, as well as the exposure to cosmic radiation, drives the organism to develop melatonin secretion disorders. In both cases, an increased risk of developing breast cancer is detected, which supports the recommendation of particular medical supervision for flight assistants for this type of cancer, and to take into account the role of other risk factors. Amongst these factors stands out the hormonal [45] [46], since their hormonal state, their geographical origin, lifestyle, and deficit of vitamin D are shown as potential mechanisms responsible for an increase of cancer for the working collective. About breast cancer, there is a possible dose-effect association, being the risk moderately increased in the presence of longer working periods, especially in women who have been working night shifts for over 20 years. In consequence, it is recommended that preventive tracking of breast cancer is carried out with the workers, as well as the evaluation of the benefit of melatonin supplements [47].

Breast cancer has probably been the most studied cancer regarding its relationships with working exposure. Epidemiologic studies indicate that physical activity reduces the risk of developing it, and it has recently been suggested that sedentary behaviour could be considered as a risk factor that acts independently from the level of physical activity. In 2017, a study evaluated working activities by classifying them into sedentary, mixed, and non-sedentary. Occupational sedentarism was associated with a greater risk of breast cancer, especially in women under the age of 55 . This factor can be modified by planning breaks during the daily working schedule, although it hasn't been confirmed whether this measure can have significant risk reduction in the medium and long term [48].

\section{Cancer in Women: Risk Factors outside Work}

There are other risk factors, such as metabolic risks, are not directly linked with the working environment, but that workspaces can help prevent through health campaigns, especially obesity. The latest is linked to an increment in the prevalence and incidence of some types of cancer. It is considered a risk factor for endometrial cancer, although it isn't clear if the metabolic syndrome contributes to a greater extent than obesity. Some authors state that metabolic syndrome doubles the risk of endometrial cancer and women with hypoglycaemia, dyslipidaemia, and hypertension have double chances of developing it. Elevated glucose levels, the increment of waist measures, and the body fat index are also associated with an incremented risk, which supports the need of tracking and control- 
ling the development of the metabolic syndrome as a possible endometrial cancer risk predictor, independently of obesity amongst women [49].

In addition to considering work-related risk factors for the prevention of cancer in women, it is also necessary to take into account that gynaecological cancers, especially breast cancer, are amongst the most frequent ones when it comes to working women. It is highly important to act in a preventive way, facilitating their return to work and investigating the characteristics that have an influence on their reincorporation after treatment. Some authors point out that, in some countries like Japan, when the work doesn't have a regular time schedule, it is more probable that it will affect negatively the return and the adaptation to changes after undergoing treatment for gynaecological cancer [50]. It is a growing issue, and both cancer and its treatment have an impact on the employees' ability to carry out their tasks, something that varies depending on the therapy received. Business policies that improve communication and work-related adaptations facilitate the return-to-work process. In the United States, it is expected that as cancer detection and treatment options improve, so will the number of cancer survivors, which stresses the importance of knowing the effects of the disease on their daily work activities. Some authors show that women who have undergone radiotherapy have higher chances of having limitations in their physical activities, whilst those who received chemotherapy see limitations in analytic activities. Only $29 \%$ of women feel that their return to work is being facilitated [51].

Preventive action is gaining importance and it can be of greater effectiveness when cooperating with Occupational and Public Health, particularly regarding uterine cancer, one of the most common types and whose early diagnosis and effective treatment are possible thanks to smear tests (Papanicolaou). Information is vital for preventing this kind of cancer and it implies improving preventive knowledge and behaviours as shown by a 2019 Turkish study about HPV, uterine cancer, and the Papanicolau test. The results highlight the insufficient knowledge there is currently across different professional and cultural fields (nurses, doctors, teachers, university staff, police officers and housekeepers) and which hinders any preventive activity. It is highlighted the weight of cultural and social factors since women who have higher levels of education, higher income and who live in urban areas have better knowledge about HPV, its vaccine, the Papanicolau test and uterine cancer. However, it stands out the fact that nurses are the ones who underwent the lowest number of gynaecological examinations; on the contrary, doctors are the ones who underwent the highest number of Papanicolau test. The scale for uterine cancer early diagnosis showed health workers at the highest end, and police officers at the lowest [52]. A decade earlier, nurses from the occidental regions of Turkey had been the subject for a study that aimed to evaluate their knowledge and attitudes towards uterine cancer. All participants considered that their knowledge was adequate, and the researchers didn't find any significant difference regarding their age, marital status nor years 
of experience [53]. Despite their good knowledge and attitude levels towards the Papanicolau test, the results showed that a low number of them had undergone it, with the main reason for it being the absence of cancer-associated symptoms. It is recommended to improve the acceptance of this test, even amongst health workers, and the working place is an ideal space for doing it through training, informative campaigns and coordinated activities with health professionals [54].

Without a doubt, genetic factors are relevant in this type of cancer, but exposure in the working space must be taken into account as part of the necessary research to establish cause-effect associations.

Epidemiological studies focused on specific professional collectives have observed a higher incidence rate or death risk by breast cancer amongst teachers, nurses and doctors, management positions, beauticians and hairdressers, chemists, telephonists and pharmacy workers. Some studies indicate that the incidence rate may hold an association with work-related exposure to electromagnetic fields, ionizing radiation, organic solvents, pesticides and low physical activity levels. Nevertheless, due to inconsistencies in the results and methodological deficiencies, it has not yet been possible to make decisive conclusions about their relationship [55].

\section{Women Work-Related Cancer in Spain}

In Spain, work-related cancer has generated very few cases of temporary incapacitation (TI) - although these have been of long duration, scarce proposals of permanent incapacitation (PI) and their notification as occupational illness (OI) in the CEPROSS database continues to be low (Table 2). Notification of cancer as OC has only slightly changed in the past decade (Figure 2) regarding both cancer types included under the official policies (Real Decreto 1299/2006, de Enfermedades profesionales) [56] (Table 3) and those which aren't. When there is a possible cause-effect association between a work-related exposure risk and the development of a neoplasm, but it cannot be classified as an OP-it will be notified as a work-related accident in the PANOTRASS database. The lack of notification of these cases affects both men and women, but it is especially alarming regarding women specific cancers, uterine, cervix, breast and ovarian

Table 2. Cancer as an occupational disease in Spain (group 6 of the RD).

\begin{tabular}{cccc}
\hline & Men & Women & Total \\
\hline Absenteeism reports & $0.57 \%$ & $0.04 \%$ & $0.30 \%$ \\
Average of sick-days & 205.09 days & 48 days & 198.54 days \\
Disability Proposals & $1.33 \%$ & 0 & $0.83 \% 1$ \\
Cancer reported as occupational disease & 23 & 1 & 24 \\
\hline
\end{tabular}

Reference:

http://www.seg-social.es/wps/portal/wss/internet/EstadisticasPresupuestosEstudios/Estadisticas/EST231. 


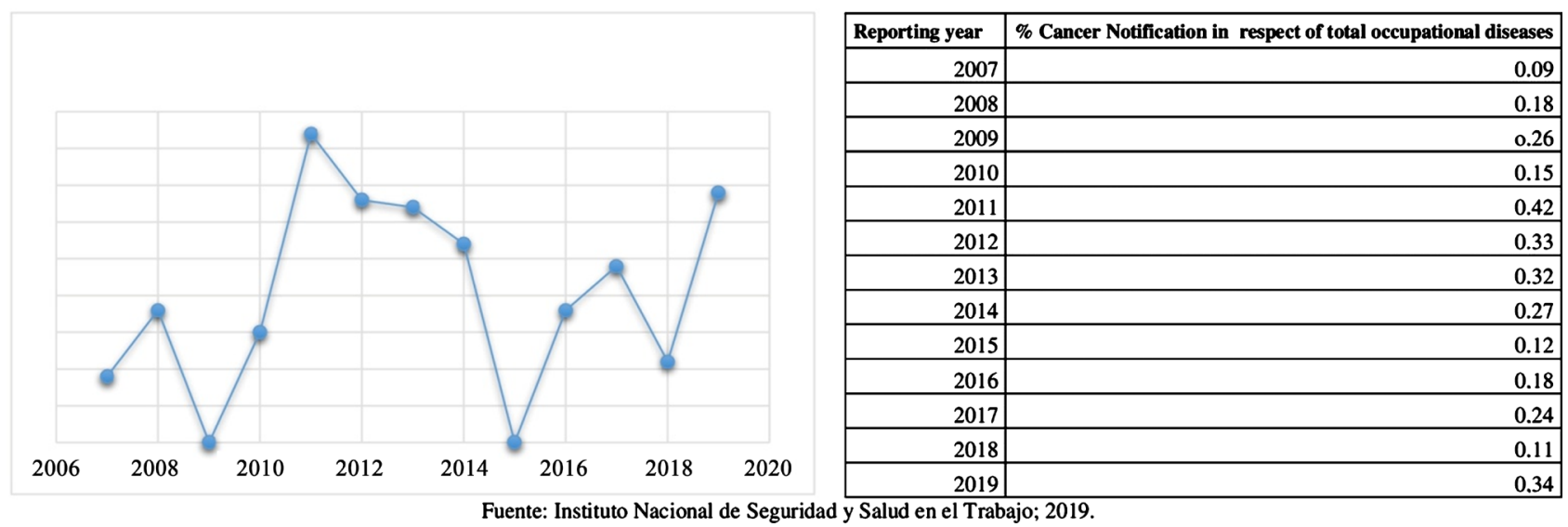

Figure 2. Evolution of the notification of cancer as an occupational diseases in Spain (2007-20019).

cancers, since none of them, is included in the above-mentioned official regulation document.

Another document to be noted due to its interesting approach is the National Occupational Security and Health Institute (INSST) document about cancerrelated mortality [57] and, more specifically, about gynaecological cancers, occupational risks, and work-related risk exposures (Table 4).

Regarding breast cancer, it is the most frequent type in Spain amongst female workers, as well as their top cause of death. Studies carried out in the working space specify risk factors, the determination of contingency, the criteria for their return-to-work evaluation, the criteria for incapacitation and disability assessments, and the costs of work absence periods [58] [59] [60] [61] [62]. Nevertheless, the absence of positive associations between breast cancer mortality rates and the specific professions clashes against the scientific evidence, since positive associations have already been found between the work-related exposure to different substances and breast cancer in women.

For uterine cancer, the highest mortality rate is found amongst workers in some construction-related activities, and it coincides with previous research results [63], although it is the hospitality waitresses collective the one that shows the highest risk [64] [65]. About cervix cancer, there are differences in the level of risk between countries and even inside each health attention area, both in terms of prevalence and survival. The key seems to be related to socioeconomic inequalities, which opens new opportunities to studies and research that gather information about these cultural, economic, and social aspects [66] [67].

There are very few published studied that connect uterine cancer with the working scene. A higher risk has been found on teachers, retail workers, and security personnel. In Spain, work carried out by the INSST shows a higher mortality risk by uterine cancer on retail workers, painters, fisherwomen, machinery operators, electricians, and lawyers, matching the results of previous studies, such as that of Wernli et al. of 2008. The same cannot be said about ovarian cancer, for which INSST hasn't found in Spain a clear association between this type of cancer and specific occupations and economic sectors. Other international 
studies states hairdressers as working collective with the highest risk [68] [69] [70]. According to the IARC, the evidence that shows an association between that profession and ovarian cancer is limited and it is related to the exposure to

Table 3. Cancer and Work in Spain. Exposure risks.

\begin{tabular}{|c|c|c|c|}
\hline Cancer location & Type of cancer & Occupational risk exposure * & $\begin{array}{l}\text { Other exposures to value not included in } \\
\text { the Royal Decree }\end{array}$ \\
\hline \multirow[t]{2}{*}{ Digestive } & $\begin{array}{l}\text { Mesothelioma of the } \\
\text { peritoneum }\end{array}$ & Asbestos main risk factor in $54 \%-90 \%$ of patients & \\
\hline & $\begin{array}{l}\text { Angiosarcoma of the } \\
\text { liver }\end{array}$ & $\begin{array}{l}\text { Arsenic and its compounds; Vinyl chloride } \\
\text { monomer }\end{array}$ & $\begin{array}{l}\text { Steroids, hemochromatosis, } \\
\text { diethylstilbestrol, phenelzine, urethane, } \\
\text { cyclophosphamide, oral contraceptives. } \\
\text { Contribute to explain the appearance of no } \\
\text { more than } 20 \% \text { of the cases published. In } \\
\text { the rest the etiology is still unknown. }\end{array}$ \\
\hline \multirow[t]{2}{*}{ Respiratory } & $\begin{array}{l}\text { Malignant neoplasm of } \\
\text { bronchus and Lung }\end{array}$ & $\begin{array}{l}\text { Asbestos; Arsenic and its compounds; Beryllium; } \\
\text { Bis-(chloromethyl) ether; Cadmium; Vinyl chloride } \\
\text { monomer; Chromium VI and chromium VI } \\
\text { compounds, Nickel and nickel compounds; Radon; } \\
\text { Free Silica Dust }\end{array}$ & $\begin{array}{l}\text { Tobacco use, second-hand smoke-passive } \\
\text { smoker and characteristics such as sex, } \\
\text { age, and non-metropolitan or } \\
\text { metropolitan residence }\end{array}$ \\
\hline & Pleural mesothelioma & Asbesto & \\
\hline Prostate & Adenocarcinoma & Occupational risks not confirmed & Age, race, and family history \\
\hline \multirow[t]{2}{*}{ Hematologic } & $\begin{array}{l}\text { Lympho and } \\
\text { myeloproliferative } \\
\text { syndrome }\end{array}$ & Benzene; Ionizing radiation & Genetic factors. \\
\hline & Linfoma: & Nitrobenzene & Genetic factors. \\
\hline Bladder and Kidney & $\begin{array}{l}\text { Malignant neoplasm of } \\
\text { bladder }\end{array}$ & $\begin{array}{l}\text { Aromatic amines; and Amines (primary, } \\
\text { secondary, tertiary, heterocyclic) and aromatic } \\
\text { hydrazines and their halogen, phenolic, nitrosated, } \\
\text { nitrated and sulfonated derivatives }\end{array}$ & $\begin{array}{l}\text { Tobacco use, exposure to certain } \\
\text { environmental and occupational } \\
\text { chemicals, and genetic factors. }\end{array}$ \\
\hline \multirow[t]{3}{*}{$\begin{array}{l}\text { Otorrino- } \\
\text { Laringological }\end{array}$} & Laryngeal cancer & Asbesto & $\begin{array}{l}\text { Smoking and alcohol, coffee and diesel } \\
\text { exhaust }\end{array}$ \\
\hline & $\begin{array}{l}\text { Malignant neoplasm of } \\
\text { nasal cavity }\end{array}$ & $\begin{array}{l}\text { Chromium VI and chromium VI compound; } \\
\text { Nickel and nickel compounds; Hardwood dust }\end{array}$ & $\begin{array}{l}\text { Consumo de tabaco y exposición a } \\
\text { plaguicidas y herbicidas. }\end{array}$ \\
\hline & $\begin{array}{l}\text { Primitive cancer of the } \\
\text { ethmoid and sinuses of } \\
\text { the face }\end{array}$ & $\begin{array}{l}\text { Nickel and nickel compounds; Hydrocyanic acid, } \\
\text { cyanides, cyanogen compounds and acrylonitriles }\end{array}$ & Exposure to wood dust \\
\hline \multirow[t]{3}{*}{ Dermatologic } & $\begin{array}{l}\text { squamous cell } \\
\text { carcinoma of the skin }\end{array}$ & Arsenic and its compounds; Ionizing radiation & $\begin{array}{l}\text { Sun exposure } \\
\text { Exposure to metal welding }\end{array}$ \\
\hline & $\begin{array}{l}\text { Lenticular disc } \\
\text { dyskeratosis (Bowen's } \\
\text { disease) }\end{array}$ & Arsenic and its compounds & Sun exposure \\
\hline & $\begin{array}{l}\text { Premalignant skin } \\
\text { lesions }\end{array}$ & $\begin{array}{l}\text { Polycyclic aromatic hydrocarbons (PAH), coal } \\
\text { distillation products: soot, tar, bitumen, pitch, } \\
\text { anthracene, mineral oils, crude paraffin and the } \\
\text { compounds, products, residues of these substances } \\
\text { and other carcinogenic factors. Coal distillation }\end{array}$ & Sun exposure \\
\hline
\end{tabular}

${ }^{*}$ Cancer report included in Royal Decree 1299/2006, of November 10, which approves the table of occupational diseases in the Social Security system and establishes criteria for their notification and registration. Spanish Ministry of Labor and Social Affairs "BOE" no. 302, of December 19, 2006 Reference: BOE-A-2006-22169. 
Table 4. Cancer and work in Spain. Mortality risk.

\begin{tabular}{|c|c|c|}
\hline Type of cancer & Occupation-risk & Economic activity-risk \\
\hline \multirow[t]{2}{*}{ Breast cancer } & $\begin{array}{l}\text { Higher risk: plumbers, electricians, policemen and assimilates, teachers, } \\
\text { other higher professions, technical and administrative assistants and } \\
\text { managers. }\end{array}$ & $\begin{array}{l}\text { Higher risk: activities of production and } \\
\text { distribution of energy and water, maritime and air } \\
\text { transport, and the sale of motor vehicles; also with a } \\
\text { significantly high risk, but less magnitude in } \\
\text { financial intermediation, associative and } \\
\text { recreational activities, education, the provision of } \\
\text { services to the community and public } \\
\text { administration. }\end{array}$ \\
\hline & $\begin{array}{l}\text { Lower risk: operators and assemblers in the manufacturing industry, } \\
\text { livestock, domestic employees, housekeeping staff, cooks and other } \\
\text { restaurant workers. }\end{array}$ & $\begin{array}{l}\text { Lower risk: livestock and hunting, households with } \\
\text { employees, housekeeping staff, agriculture and } \\
\text { forestry, hotels and similar, and restaurants. }\end{array}$ \\
\hline \multirow[t]{2}{*}{ Cervical cancer } & $\begin{array}{l}\text { Higher risk: service sector female workers, in particular in public } \\
\text { sanitation activities, beverage establishments, households with employees } \\
\text { and housekeeping staff, and in general construction of buildings } \\
\text { Women bricklayers and assimilated women, cooks, waitresses, other } \\
\text { restoration workers, domestic workers and housekeeping staff. }\end{array}$ & $\begin{array}{l}\text { Higher risk: hotels and restaurants, with beverage } \\
\text { establishments being those with the highest risk. } \\
\text { housekeeping staff and households with employees. }\end{array}$ \\
\hline & $\begin{array}{l}\text { Lower risk: secondary and higher education and health activities. } \\
\text { Professors, teachers and assimilated, medical and assimilated, other } \\
\text { senior professionals and administrative techniques. }\end{array}$ & Lower risk: teaching, health and services sector. \\
\hline \multirow[t]{2}{*}{$\begin{array}{l}\text { Uterine body } \\
\text { cancer }\end{array}$} & $\begin{array}{l}\text { Higher risk: shop assistants, painters, fisherwomen/sailors, machine } \\
\text { operators, electricians, lawyers and similar. }\end{array}$ & $\begin{array}{l}\text { Higher risk: metallurgy, sale of motor ve- } \\
\text { hicles/components, food retail, agriculture and } \\
\text { forestry; a higher risk was also identified in fishing } \\
\text { activities and public sanitation. }\end{array}$ \\
\hline & Lower risk: cooks and teachers and assimilated. & Lower risk: primary school workers. \\
\hline Ovarian cancer & $\begin{array}{l}\text { Higher risk: industrial occupations (glass/ceramics/processing of } \\
\text { non-metallic minerals, other mechanics and plastic workers) and services } \\
\text { (police and street vendors) which, together with some industrial activities } \\
\text { (chemical, tool making and metal products, furniture manufacturing, } \\
\text { business services, motor vehicle maintenance). } \\
\text { Lower risk: women workers in the food industry, wood/paper, footwear/ } \\
\text { leather, or meat industries, and in transport or service activities, such as } \\
\text { food wholesaling. }\end{array}$ & $\begin{array}{l}\text { By economic activity, no heading was found with a } \\
\text { statistically significant risk above the average. }\end{array}$ \\
\hline
\end{tabular}

Reference: Spanish National Institute of Safety and Health at Work; 2019.

different kinds of dies (amines, aromatics, aminophenol), solvents, propellant substances, and aerosols. Ovarian cancer seems to be connected with dry cleaning activities, printing, and graphic arts, agriculture or the pharmaceutical industry, as well as with other specific occupations such as nursing or teaching. It has also been found a possible relationship with the exposure to combustion-derived fumes, solvents, and silica powders [71]-[78]. The IARC highlights asbestos in its multiple forms as the only work-related exposure agent to which there is enough evidence for establishing an association [79].

From this revision it can be highlighted that the data is not conclusive enough to draw a clear association between these types of cancer that affect women and their relationship with the working field, although the evidence is continuously becoming clearer and lead the way to the future investigation; this is particularly important in our days, at a moment when cancer is still a disease that affects all 
countries and which incidence and prevalence keeps growing, with sanitary, economic and social implications.

Occupational cancer is the least notified OP in Spain and its surrounding countries, and it requires multidisciplinary and collaborative measures in order to be tackled and approximate real data about it.

For studying work-related cancer in women it is crucial to have a gender view that allows the encouragement of preventive activities, anticipating the action to the possible damage, and to facilitate a return to work process without as many risks as possible after surviving the disease.

Good health at work has a very important role in this, and occupational health as a preventive health specialty enables professionals to collaborate from all related competencies: health promotion, risk prevention, specific health screening, formation, training, specialised information, and investigation focused on the working field and, in this case, women.

The present research has not received any funding from agencies related to neither the public, commercial nor non-profit sectors.

\section{Conflicts of Interest}

The authors declare no conflicts of interest regarding the publication of this paper.

\section{References}

[1] Mattiuzzi, C. and Lippi, G. (2019) Current Cancer Epidemiology. Journal of Epidemiology and Global Health, 9, 217-222. https://doi.org/10.2991/jegh.k.191008.001

[2] World Health Organization (2018) Global Health Estimates 2016: Disease Burden by Cause, Age, Sex, by Country and by Region, 2000-2016. World Health Organization, Geneva. https://www.who.int/healthinfo/global_burden_disease/estimates/en/index1.html

[3] International Agency for Research on Cancer (2020) Global Cancer Observatory-Cancer Fact Sheets. http://gco.iarc.fr/today/fact-sheets-cancers

[4] Takala, J. (2015) Eliminating Occupational Cancer. Industrial Health, 53, 307-309.

[5] European Commission (2016) Employment, Social Affairs \& Inclusion. http://ec.europa.eu/social/main.jsp?langId=en\&catId=89\&newsId=2536\&furtherNe ws=yes

[6] Zahm, S.H. and Blair, A. (2003) Occupational Cancer among Women: Where Have We Been and Where Are We Going? American Journal of Industrial Medicine, 44, 565-575. https://doi.org/10.1002/ajim.10270

[7] Bounin, A., Charbotel, B., Fervers, B. and Bergeret, A. (2014) Professional Risk Factors Associated with the Cancer of the Ovary. Literature Review. Bulletin du Cancer, 101, 1089-1108. https://doi.org/10.1684/bdc.2014.1978

[8] Health and Safety Executive (2012) The Burden of Occupational Cancer in Great Britain: Breast Cancer. Health and Safety Executive. http://www.hse.gov.uk/research/rrpdf/rr852.pdf

[9] Braem, M.G., Onland-Moret, N.C., Schouten, L.J., Kruitwagen, R.F., Lukanova, A., Allen, N.E., et al. (2012) Multiple Miscarriages Are Associated with the Risk of Ovarian Cancer: Results from the European Prospective Investigation into Cancer and 
Nutrition. PLoS ONE, 7, e37141. https://doi.org/10.1371/journal.pone.0037141

[10] Permuth-Wey, J. and Sellers, T.A. (2009) Epidemiology of Ovarian Cancer. In: Verma, M., Ed., Cancer Epidemiology, Vol. 472, Humana Press, 413-437.

[11] Hinkula, M., Pukkala, E., Kyyrönen, P. and Kauppila, A. (2006) Incidence of Ovarian Cancer of Grand Multiparous Women-A Population-Based Study in Finland. Gynecologic Oncology, 103, 207-211. https://doi.org/10.1016/j.ygyno.2006.02.025

[12] Goldberg, M.S. and Labrèche, F. (1996) Occupational Risk Factors for Female Breast Cancer: A Review. Occupational and Environmental Medicine, 53, 145-156. https://doi.org/10.1136/oem.53.3.145

[13] García, A.M. (2003) Pesticide Exposure and Women's Health. American Journal of Industrial Medicine, 44, 584-594. https://doi.org/10.1002/ajim.10256

[14] Ali, K.E., Mohammed, I.A., Difabachew, M.N., Demeke, D.S., Haile, T., Ten Hove, R.J., et al. (2019) Burden and Genotype Distribution of High-Risk Human Papillomavirus Infection and Cervical Cytology Abnormalities at Selected Obstetrics and Gynecology Clinics of Addis Ababa, Ethiopia. BMC Cancer, 19, Article No. 768. https://doi.org/10.1186/s12885-019-5953-1

[15] Wesseling, C., Antich, D., Hogstedt, C., Rodríguez, A.C. and Ahlbom, A. (1999) Geographical Differences of Cancer Incidence in Costa Rica in Relation to Environmental and Occupational Pesticide Exposure. International Journal of Epidemiology, 28, 365-374. https://doi.org/10.1093/ije/28.3.365

[16] Li, B., Wang, L., Lu, M.-S., Mo, X.-F., Lin, F.-Y., Ho, S.C., et al. (2015) Passive Smoking and Breast Cancer Risk among Non-Smoking Women: A Case-Control Study in China. PLoS ONE, 10, e0125894.

https://doi.org/10.1371/journal.pone.0125894

[17] Shen, N., Weiderpass, E., Antilla, A., Goldberg, M.S., Vasama-Neuvonen, K.M., Boffetta, P., et al. (1998) Epidemiology of Occupational and Environmental Risk Factors Related to Ovarian Cancer. Scandinavian Journal of Work, Environment \& Health, 24, 175-182. https://doi.org/10.5271/sjweh.296

[18] Cogliano, V.J., Baan, R., Straif, K., Grosse, Y., Lauby-Secretan, B., El Ghissassi, F., et al. (2011) Preventable Exposures Associated with Human Cancers. Journal of the National Cancer Institute, 103, 1827-1839. https://doi.org/10.1093/jnci/djr483

[19] Collaborative Group on Epidemiological Studies of Ovarian Cancer (2012) Ovarian Cancer and Smoking: Individual Participant Meta-Analysis Including 28,114 Women with Ovarian Cancer from 51 Epidemiological Studies. The Lancet Oncology, 13, 946-956. https://doi.org/10.1016/S1470-2045(12)70322-4

[20] International Collaboration of Epidemiological Studies of Cervical Cancer (2006) Carcinoma of the Cervix and Tobacco Smoking: Collaborative Reanalysis of Individual Data on 13,541 Women with Carcinoma of the Cervix and 23,017 women without Carcinoma of the Cervix from 23 Epidemiological Studies. International Journal of Cancer, 118, 1481-1495. https://doi.org/10.1002/ijc.21493

[21] Fonseca-Moutinho, J.A. (2011) Smoking and Cervical Cancer. International Scholarly Research Notice, 2011, Article ID: 847684. https://doi.org/10.5402/2011/847684

[22] Health and Safety Executive (2012) The Burden of Occupational Cancer in Great Britain-Technical Report: Cervical Cancer. Health and Safety Executive. http://www.hse.gov.uk/cancer/

[23] American Institute for Cancer Research (2007) Food, Nutrition, Physical Activity, and the Prevention of Cancer: A Global Perspective. World Cancer Research Fund, American Institute for Cancer Research, Washington DC. 
[24] Sturgeon, S.R., Brock, J.W., Potischman, N., Needham, L.L., Rothman, N., Brinton, L.A., et al. (1998) Serum Concentrations of Organochlorine Compounds and Endometrial Cancer Risk (United States). Cancer Causes \& Control, 9, 417-424. https://doi.org/10.1023/A:1008823802393

[25] WHO (World Health Organization)/UNEP (United Nations Environment Programme) (2013) The State-of-the-Science of Endocrine Disrupting Chemicals-2012. (Bergman, Å., Heindel, J.J., Jobling, S., Kidd, K.A. and Zoeller, R.T., Eds.), (Consultado el 15/12/2017). United Nations Environment Programme/World Health Organization, Geneva. http://www.who.int/ceh/publications/endocrine/en/index.html

[26] Liu, J.H., Black, D.R., Larkin, L., Graham, S., Bernick, B. and Mirkin, S. (2020) Breast Effects of Oral, Combined 17 $\beta$-estradiol, and Progesterone Capsules in Menopausal Women: A Randomized Controlled Trial. Menopause, 27, 1388-1395. https://doi.org/10.1097/GME.0000000000001631

[27] Charbotel, B., Fervers, B. and Droz, J.P. (2014) Occupational Exposures in Rare Cancers: A Critical Review of the Literature. Critical Reviews in Oncology/Hematology, 90, 99-134. https://doi.org/10.1016/j.critrevonc.2013.12.004

[28] Rushton, L., Bagga, S., Bevan, R., Brown, T., Cherrie, J., Holmes, P., et al. (2012) The Burden of Occupational Cancer in Great Britain-Technical Report: Ovarian Cancer. British Journal of Cancer, 107, 3-7. https://doi.org/10.1038/bjc.2012.112 https://www.hse.gov.uk/research/rrpdf/rr931.pdf

[29] Weiderpass, E., Pukkala, E., Vasama-Neuvonen, K., Kauppinen, T., Vainio, H., Paakkulainen, H., et al. (2001) Occupational Exposures and Cancers of the Endometrium and Cervix Uteri in Finland. American Journal of Industrial Medicine, 39, 572-580. https://doi.org/10.1002/ajim.1056

[30] Clapp, R.W., Jacobs, M.M. and Loechler, E.L. (2008) Environmental and Occupational Causes of Cancer New Evidence, 2005-2007. Reviews on Environmental Health, 23, 1-37. https://doi.org/10.1515/REVEH.2008.23.1.1

[31] Savitz, D.A., Andrews, K.W. and Brinton, L.A. (1995) Occupation and Cervical Cancer. Journal of Occupational and Environmental Medicine, 37, 357-361. https://doi.org/10.1097/00043764-199503000-00013

[32] Slack, R., Young, C. and Rushton, L. (2012) British Occupational Cancer Burden Study Group. Occupational Cancer in Britain. Female Cancers: Breast, Cervix and Ovary. British Journal of Cancer, 107, S27-S32. https://doi.org/10.1038/bjc.2012.115

[33] Sathiakumar, N. and Delzell, E. (2009) A Follow-up Study of Mortality among Women in the North American Synthetic Rubber Industry. Journal of Occupational and Environmental Medicine, 51, 1314-1325.

https://doi.org/10.1097/JOM.0b013e3181bd8972

[34] Lee, D.G., Burstyn, I., Lai, A.S., Grundy, A., Friesen, M.C., Aronson, K.J. and Spinelli, J.J. (2019) Women's Occupational Exposure to Polycyclic Aromatic Hydrocarbons and Risk of Breast Cancer. Occupational and Environmental Medicine, 76, 22-29. https://doi.org/10.1136/oemed-2018-105261

[35] Macon, M.B. and Fenton, S.E. (2013) Endocrine Disruptors and the Breast: Early Life Effects and Later Life Disease. Journal of Mammary Gland Biology and Neoplasia, 18, 43-61. https://doi.org/10.1007/s10911-013-9275-7

[36] Ekenga, E.C., Parks, C.G., D’Aloisio, A.A., DeRoo, L.A. and Sandler, D.P. (2014) Breast Cancer Risk after Occupational Solvent Exposure: The Influence of Timing and Setting. Cancer Research, 74, 3076-3083. https://doi.org/10.1158/0008-5472.CAN-13-2430

[37] Brophy, J.T., Keith, M.M., Watterson, A., Park, R., Gilbertson, M., MatickaTyndale, E., Beck, M., Abu-Zahra, H., Schneider, K., Reinhartz, A., Dematteo, R. 
and Luginaah, I. (2012) Breast Cancer Risk in Relation to Occupations with Exposure to Carcinogens and Endocrine Disruptors: A Canadian Case-Control study. Environmental Health, 11, Article No. 87. https://doi.org/10.1186/1476-069X-11-87

[38] Villeneuve, S., Cyr, D., Lynge, E., Orsi, L., Sabroe, S., Merletti, F., et al. (2010) Occupation and Occupational Exposure to Endocrine Disrupting Chemicals in Male Breast cancer: A Case-Control Study in Europe. Occupational and Environmental Medicine, 67, 837-844. https://doi.org/10.1136/oem.2009.052175

[39] Preston, L.D., Kitahara, C.M., Freedman, D.M., Sigurdson, A.J., Simon, S.L., Littl, M.P., et al. (2016) Breast Cancer Risk and Protracted Low-to-Moderate Dose Occupational Radiation Exposure in the US Radiologic Technologists Cohort, 19832008. British Journal of Cancer, 115, 1105-1112.

https://doi.org/10.1038/bjc.2016.292

[40] Fenga, C. (2016) Occupational Exposure and Risk of Breast Cancer (Review). Biomedical Reports, 4, 282-292. https://doi.org/10.3892/br.2016.575

[41] Betenia, N., Costello, S. and Eisen, E.A. (2012) Risk of Cervical Cancer among Female Autoworkers Exposed to Metalworking Fluids. Scandinavian Journal of Work, Environment \& Health, 38, 78-83. https://doi.org/10.5271/sjweh.3193

[42] Centers for Disease Control and Prevention (CDC) (2017) Cáncer de cuello uterino. Centros para el Control y la Prevención de Enfermedades. 99-9123, Departamento de Salud y Servicios Humanos de los EE. UU. https://www.cdc.gov

[43] Soohoo, M., Blas, M., Byraiah, G., Carcamo, C. and Brown, B. (2013) Cervical HPV Infection in Female Sex Workers: A Global Perspective. The Open AIDS Journal, 7, 58-66. https://doi.org/10.2174/1874613601307010058

[44] Pinkerton, L.E., Hein, M.J., Anderson, J.L., Christianson, A., Little, M.P., Sigurdson, A.J. and Schubauer-Berigan, M.K. (2018) Melanoma, Thyroid Cancer, and Gynecologic Cancers in a Cohort of Female Flight Attendants. American Journal of Industrial Medicine, 61, 572-581. https://doi.org/10.1002/ajim.22854

[45] Gassmann, A.S., Gonzalez, M. and Mathelin, C. (2015) Have Female Flight Attendants an Over-Risk of Breast Cancer? Gynécologie Obstétrique \& Fertilité, 43, 4148. https://doi.org/10.1016/j.gyobfe.2014.09.008

[46] Rafnsson, V., Tulinius, H., Jónasson, J.G. and Hrafnkelsson, J. (2001) Risk of Breast Cancer in Female Flight Attendants: A Population-Based Study (Iceland). Cancer Causes \& Control, 12, 95-101. https://doi.org/10.1023/A:1008983416836

[47] Benabu, J.C., Stoll, F., Gonzalez, M. and Mathelin, C. (2015) Night Work, Shift Work: Breast Cancer Risk Factor? Gynécologie Obstétrique \& Fertilité, 43, 791-799. https://doi.org/10.1016/j.gyobfe.2015.10.004

[48] Johnsson, A., Broberg, P., Johnsson, A., Tornberg, A.B. and Olsson, H. (2017) Occupational Sedentariness and Breast Cancer Risk. Acta Oncologica, 56, 75-80. https://doi.org/10.1080/0284186X.2016.1262547

[49] Arthur, R.S., Kabat, G.C., Kim, M.Y., Wild, R.A., Shadyab, A.H., WactawskiWende, J., et al. (2019) Metabolic Syndrome and Risk of Endometrial Cancer in Postmenopausal Women: A Prospective Study. Cancer Causes \& Control, 30, 355-363. https://doi.org/10.1007/s10552-019-01139-5

[50] Nakamura, K., Masuyama, H., Nishida, T., Haraga, J., Ida, N., Saijo, M., et al. (2016) Return to Work after Cancer Treatment of Gynecologic Cancer in Japan. BMC Cancer, 16, Article No. 558. https://doi.org/10.1186/s12885-016-2627-0

[51] Nachreiner, N.M., Shanley, R. and Ghebre, R.G. (2013) Cancer and Treatment Effects on Job Task Performance for Gynecological Cancer Survivors. Work, 46, 433 438. https://doi.org/10.3233/WOR-131752 
[52] Cimke, V.S. and Borekci, G. (2019) The Determination of the Knowledge Level and Behavior of Turkish Women from Various Occupations about Human Papillomavirus, Cervical Cancer, and Pap Smear Test. Journal of Cancer Research and Therapeutics, 15, 1235-1244. https://doi.org/10.4103/jcrt.JCRT_1195_16

[53] Ertem, G. (2009) Awareness of Cervical Cancer Risk factors and Screening Behaviour among Nurses in a Rural Region of Turkey. Asian Pacific Journal of Cancer Prevention, 10, 735-738.

[54] Swapnajaswanth, M., Suman, G., Suryanarayana, S.P. and Murthy, N.S. (2014) Perception and Practices on Screening and Vaccination for Carcinoma Cervix among Female Healthcare Professional in Tertiary Care Hospitals in Bangalore, India. Asian Pacific Journal of Cancer Prevention, 15, 6095-6098.

https://doi.org/10.7314/APJCP.2014.15.15.6095

[55] Pepłońska, B. and Szeszenia-Dabrowska, N. (2001) Occupational Risk Factors for Breast Cancer in the Epidemiological Studies. Medycyna Pracy, 52, 483-495.

[56] Real Decreto 1299/2006, de 10 de noviembre, por el que se aprueba el cuadro de enfermedades profesionales en el sistema de la Seguridad Social y se establecen criterios para su notificación y registro. Ministerio de Trabajo y Asuntos Sociales “BOE” núm. 302, de 19 de diciembre de 2006.

[57] Instituto Nacional de Seguridad y Salud en el Trabajo, O.A., M.P. Ocupación, Actividad económica y Mortalidad por Cáncer en España; 2019.

http://C:/Users/C003891/Downloads/Mortalidad\%20cancer.pdf

[58] Vicente-Herrero, M.T., Capdevila García, L., Ramírez Iñiguez de la Torre, M.V., Terradillos García, M.J., Aguilar Jiménez, E. and López González, A.A. (2013) Cáncer de mama en España: factores de riesgo y determinación de contingencia laboral. Revista Mexicana de Salud en el Trabajo, 5, 85-95.

[59] Vicente-Herrero, M.T., Ramírez Iñiguez de la Torre, M.V., Terradillos García, M.J., Capdevila García, L., Aguilar Jiménez, E. and López González, A.A. (2013) Valoración de aptitud laboral en la incorporación del trabajador con cáncer de mama. Revisión desde la legislación española en prevención de riesgos laborales. CES Salud Pública, 4, 65-76.

[60] Vicente-Herrero, M.T., Terradillos García, M.J., Ramírez Iñiguez de la Torre, M.V., Capdevila García, L. and López González, A.A. (2013) Criterios de incapacidad laboral en cáncer de mama. Semergen, 39, 95-100. https://doi.org/10.1016/j.semerg.2012.04.011

[61] Vicente-Herrero, M.T., Terradillos García, M.J., Ramírez Iñiguez de la Torre, M.V., Capdevila García, L., Aguilar Jiménez, E. and López González, A.A. (2013) Cáncer de mama y discapacidad. Criterios de valoración y controversias médico-legales. Revista de Senología y Patología Mamaria, 26, 99-105. https://doi.org/10.1016/j.senol.2013.06.001

[62] Vicente-Herrero, M.T., Terradillos García, M.J., Ramírez Iñiguez de la Torre, M.V., Capdevila García, L., Aguilar Jiménez, E. and López González, A.A. (2010) El cáncer de mama en España. Aproximación a su coste económico por incapacidad temporal durante. Gaceta Mexicana de Oncología, 11, 351-357.

[63] Pukkala, E., Martinsen, J.I., Lynge, E., Gunnarsdottir, H.K., Sparén, P., Tryggvadottir, L., et al. (2009) Occupation and Cancer-Follow-Up of 15 Million People in Five Nordic Countries. Acta Oncologica, 48, 646-790. https://doi.org/10.1080/02841860902913546

[64] Carpenter, L. and Roman, E. (1999) Cancer and Occupation in Women: Identifying Associations Using Routinely Collected National Data. Environmental Health Perspectives, 107, 299-303. https://doi.org/10.1289/ehp.99107s2299 
[65] Kjaerheim, K. and Andersen, A. (1994) Cancer Incidence among Waitresses in Norway. Cancer Causes Control, 5, 31-37. https://doi.org/10.1007/BF01830724

[66] Temmerman, M. (2014) Address Inequality: Prevent Cervical Cancer. Commentary Media Centre. World Health Organization, Geneva.

http://www.who.int/mediacentre/commentaries/cervical-cancer-prevention/en/

[67] Stewart, B.W. and Wild, C.P. (2014) Word Cancer Report. International Agency for Research on Cancer, Lyon.

[68] Wernli, K.J., Ray, R.M., Gao, D.L., Fitzgibbons, E.D., Camp, J.E., Astrakianakis, G.S., et al. (2008) Occupational Risk Factors for Endometrial Cancer among Textile Workers in Shanghai, China. American Journal of Industrial Medicine, 51, 673-679. https://doi.org/10.1002/ajim.20614

[69] Vasama-Neuvonen, K., Pukkala, E., Paakkulainen, H., Mutanen, P., Weiderpass, E., Boffetta, P., Shen, N., Kauppinen, T., Vainio, H. and Partanen, T. (1999) Ovarian cancer and Occupational Exposures in Finland. American Journal of Industrial Medicine, 36, 83-89.

https://doi.org/10.1002/(SICI)1097-0274(199907)36:1<83::AID-AJIM12>3.0.CO;2-Q

[70] Boffetta, P., Andersen, A., Lynge, E., Barlow, L. and Pukkala, E. (1994) Employment as Hairdresser and Risk of Ovarian Cancer and Non-Hodgkin's Lymphomas among Women. Journal of Occupational Medicine, 36, 61-65.

[71] Shields, T., Gridley, G., Moradi, T., Adami, J., Plato, N. and Dosemeci, M. (2002) Occupational Exposures and the Risk of Ovarian cancer in Sweden. American Journal of Industrial Medicine, 42, 200-213. https://doi.org/10.1002/ajim.10099

[72] International Agency for Research on Cancer (2010) Monographs on the Evaluation of Carcinogenic Risks to Humans. Some Aromatic Amines, Organic Dyes, and Related Exposures. Vol. 99, International Agency for Research on Cancer (IARC), Lyon.

[73] Weiderpass, E. and Labrèche, F. (2012) Malignant Tumors of the Female Reproductive System. Safety and Health at Work, 3, 166-180.

https://doi.org/10.5491/SHAW.2012.3.3.166

[74] Lie, J., Andersen, A. and Kjærheim, K. (2007) Cancer Risk among 43,000 Norwegian Nurses. Scandinavian Journal of Work, Environment \& Health, 33, 66-73. https://doi.org/10.5271/sjweh.1066

[75] MacArthur, A.C., Le, N.D., Abanto, Z.U. and Gallagher, R.P. (2007) Occupational Female Breast and Reproductive Cancer Mortality in British Columbia, Canada, 1950-94. Occupational Medicine, 57, 246-253.

https://doi.org/10.1093/occmed/kqm002

[76] Guo, J., Kauppinen, T., Kyyronen, P., Heikkila, P., Lindbohm, M.L. and Pukkala, E. (2004) Risk of Esophageal, Ovarian, Testicular, Kidney and Bladder Cancers and Leukemia among Finnish Workers Exposed to Diesel or Gasoline Engine Exhaust. International Journal of Cancer, 111, 286-292. https://doi.org/10.1002/ijc.20263

[77] Weirderpass, E., Meo, M. and Vainio, H. (2011) Risk Factors for Breast Cancer, Including Occupational Exposures. Safety and Health at Work, 2, 1-8.

https://doi.org/10.5491/SHAW.2011.2.1.1

[78] Charbotel, B., Fervers, B. and Droz, J.P. (2014) Occupational Exposures in Rare Cancers: A Critical Review of the Literature. Critical Reviews in Oncology/ Hematology, 90, 99-134. https://doi.org/10.1016/j.critrevonc.2013.12.004

[79] Camargo, M.C., Stayner, L.T., Straif, K., Reina, M., Al-Alem, U., Demers, P.A. and Landrigan, P.J. (2011) Occupational Exposure to Asbestos and Ovarian Cancer: A Meta-Analysis. Environmental Health Perspectives, 119, 1211-1317. https://doi.org/10.1289/ehp.1003283 